\title{
Correspondence Analysis in the Assessment of the Influence of Lifestyle on Infertility of Various Origins
}

\author{
Adrianna Zańko ${ }^{1}$, Karolina Milewska ${ }^{2}$, Robert Milewski $^{3}$ \\ 1 Doctoral studies, Medical University of Bialystok, Poland \\ 2 Scientific Group at Department of Statistics and Medical Informatics, Medical Univer- \\ sity of Bialystok, Poland \\ 3 Department of Statistics and Medical Informatics, Medical University of Bialystok, \\ Poland
}

\begin{abstract}
Approx. 60-80 million couples globally are affected by the problem of infertility. The issue is important both for the couple trying to conceive and for the whole society in which the couple lives. Lifestyle, including nutrition, may have both a positive and a negative impact on the outcomes of infertility treatment. The aim of this paper is to assess the relationship between knowledge in the area of fertility diet and its actual use, and types of fertility disorders among women undergoing treatment in a fertility clinic. A group of women was analyzed statistically, divided into 3 groups according to their couple's cause of infertility - the causes of infertility were described as: the male factor, the female factor, and the idiopathic factor. The study group answered questions that comprised a fertility diet knowledge test; the frequency of consumption of particular food products in a individual groups was also analyzed. Correspondence analysis showed differences between the groups in the number of points scored in the fertility diet knowledge test, as well as in the consumption of sweets, crisps and sticks, and nuts and seeds. Women among whom the main cause of infertility was defined as the male factor scored the highest numbers of points in the fertility diet knowledge test, women with the idiopathic cause of infertility scored slightly lower numbers of points, while women whose main cause of infertility was defined as the female factor scored the lowest numbers of points. Women from couples with idiopathic infertility consumed sweets, crisps and sticks the most often, followed by women with the cause of infertility identified on their side, with the lowest frequency of consumption of sweets identified among women whose partner was infertile. Nuts and seeds were consumed the most frequently by women whose partners were infertile, followed by women with the cause of infertility identified on their side, while women with the idiopathic cause of infertility consumed nuts and seeds the least frequently. These examples show that correspondence analysis is well suited to the assessment of the influence of lifestyle on fertility; in addition, it makes it possible to recognize certain correlations that may not be observed in standard statistical tests.
\end{abstract}




\section{Introduction}

World Health Organization (WHO) statistics concerning infertility problems show that they affect approx. 60-80 million couples globally, of whom approx. 10-12 percent are citizens of highly developed countries (Koperwas \& Głowacka, 2017). As far as Polish statistics are concerned, it is estimated that approx. 3 million Polish men and women are affected by infertility. However, new studies in this area are required. International Classification of Diseases (IDC) places this disorder among social diseases, next to diseases such as obesity, hypertension, or diabetes. Diagnostics and treatment of infertility is recognized as a huge problem due to the fact that the condition affects a couple rather than an individual. Moreover, it is not necessarily tantamount to a particular disease that affects either person both partners may be healthy but still fail to conceive (Skreczko, 2017).

Several classifications of infertility exist, for example the division into primary and secondary infertility; the condition can also be divided according to its cause. As far as percentages are concerned, studies show that in approx. $70 \%$ of couples, infertility is due to either of the partner, with the number split evenly between males and females; in 10\% of couples both partners are affected; while in $20 \%$ of couples the cause of infertility cannot be identified, in which case the disorder is called idiopathic infertility (Koperwas \& Głowacka, 2017). Among the causes of female infertility there are the following disorders: endometriosis, ovulation disorders, fallopian tube obstruction, the cervical factor, the uterine factor, as well as infectious and immunological diseases. Among men, the causes of infertility are, among others: the testicular, pre-testicular and post-testicular factors such as: systemic diseases, testicular traumas, obstruction or absence of vas deferens, congenital or developmental testicular dysfunctions, varicocele, sperm transportation disorders, erectile dysfunctions, absence or obstruction of epididymis, as well as the influence of drugs (Koperwas \& Głowacka, 2017).

The adverse effects of infertility affect both the couple trying to conceive and society. The couple would experience considerable mental strain due to the lack of possibility to fulfill themselves as parents; with thoughts of being third-rate or depressive states connected with the difficult situation a distinct possibility (Dragowski et al., 2015; Łukaszuk et al., 2018). Considering the problem from the point of view of society - infertility leads to a population decline, which has a particularly negative impact on countries experiencing demographic decline. Infertility also affects macroeconomic indicators, i.e. the factor that determines the quality of life of society as a whole 
(Drągowski et al., 2015; Łukaszuk et al., 2018). Hence, undertaking actions aimed at fighting infertility seems necessary, both from the point of view of society and of the health of each individual (Łukaszuk et al., 2018).

The current state of knowledge concerning the influence of lifestyle on health confirms that diet has an impact on the body as a whole. This means that it also affects the human reproductive system, the reproductive processes, and the production of fertility hormones. Furthermore, it is a wellknown fact that both low and excess body weight, both in women and men, are correlated with pathologies of reproductive processes and pregnancy complications (Gambineri et al., 2019; Suliga \& Głuszek 2019; SzostakWęgierek 2011).

The least invasive assisted reproductive technique is expectant management, most commonly used in cases of idiopathic infertility. Trying to conceive for an extended time, with an adjusted lifestyle and regular intercourse, may lead to natural insemination (Eukaszuk et al., 2018). As far as working on lifestyle changes is concerned, it is necessary to make adjustments to nutritional behavior, physical activity, and techniques of stress reduction.

The aim of this paper was to assess the relationship between knowledge in the area of fertility diet and its actual use, and fertility disorder types among women undergoing treatment in a fertility clinic.

\section{Materials and Methods}

The study was performed in couples affected by the problem of infertility. The couples were patients of the KRIOBANK infertility treatment center. An own questionnaire created on the basis of the latest studies concerning the influence of nutrition on human fertility was used for the assessment of the components of lifestyle, including nutritional behavior and knowledge concerning its impact on fertility.

The group consisted of 52 persons, 18 men and 34 women. The age of the tested men was 29 to 45 years, with an average age of $36 \pm 4.8$ years. The average BMI in the group of men was $25.36 \pm 4.44$; there were no underweight persons, 4 persons had normal body weight, 9 persons were overweight, and 5 persons were obese.

The age of the tested women was 24 to 45 years, with an average age of $34 \pm 4.98$ years. The average BMI in the group of women was $25.36 \pm 4.62$; there were 2 underweight persons, 23 persons had normal body weight, 4 persons were overweight, and 4 persons were obese. 
The average time of trying to conceive was 2 to 5 years. Correspondence analysis was only performed in the group of women, among whom $27 \%$ were those whose main cause of infertility was identified as the male factor, $48 \%$ were those whose main cause of infertility was identified as the female factor, while $24 \%$ were those with idiopathic infertility (Figure 1).

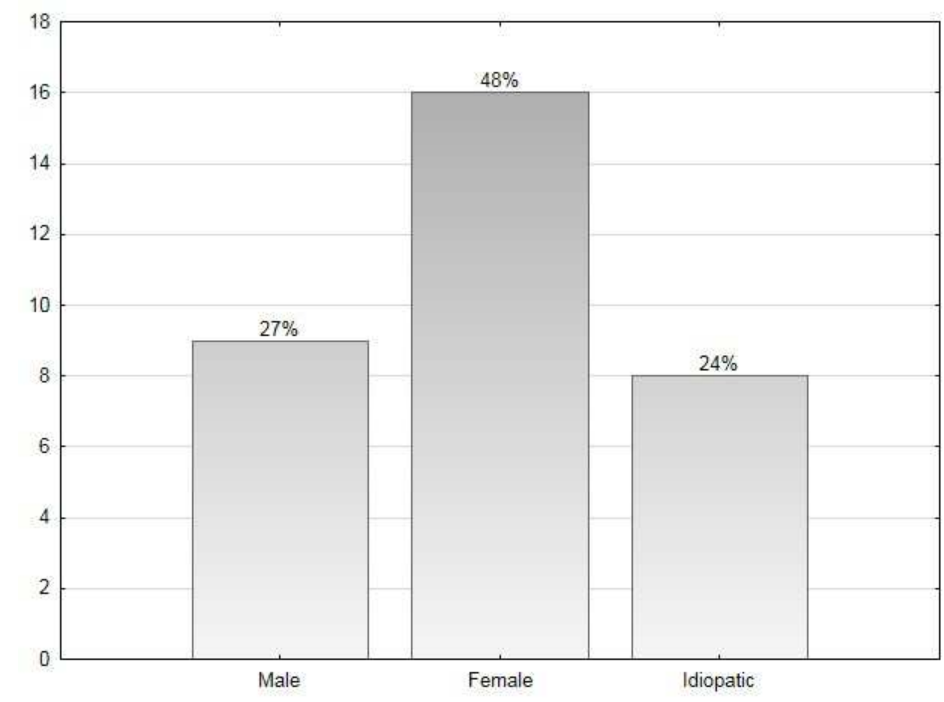

Figure 1. Causes of infertility

In the statistical analysis, correspondence analysis was used to present coexistence of characteristics. The Statistica 13.3 package by TIBCO Software Inc. was used for calculations.

Correspondence analysis is a method that makes it possible to present large contingency tables in graphical form (Jończyk \& Olszewska, 2016; Milewska et al., 2012). The method belongs to the group of multidimensional exploratory techniques. Graphic presentation of the results of analyses consists in plotting the points that illustrate categories of characteristics, most commonly on a two-dimensional coordinate system, losing as little information about the real structure of relationships between them as possible (Greencare \& Hastie, 1987). Interpretation of a correspondence map consists in the assessment of the positions of points illustrating the categories of the plotted variables. The points describing categories of different characteristics that lay close to each other indicate the existence of relationships between categories. On the other hand, categories do not co-exist when the points that illustrate them lay on opposite sides of the projection (Stanimir, 2008). 


\section{Results and Discussion}

On the basis of the correspondence analysis, correlations between the knowledge the surveyed women possess concerning fertility diet and its use, and various factors causing infertility could be determined. Women among whom the main cause of infertility was determined as the male factor scored the highest numbers of points in the fertility diet knowledge test, whereas women among whom the main cause of infertility was identified as the female factor scored the lowest numbers of points (Figure 2). This may suggest that women with the male factor as the cause of infertility were more engaged in education in the area of the influence of diet on fertility, possibly in order to make adjustments to the partners' lifestyles. This may stem from their higher empathy, which - according to studies - is a characteristic feature of women (Kaźmierczak, 2008). On the other hand, the low knowledge among those women among whom the cause of infertility was on their side may indicate a lack of focus on adjusting their lifestyles. Women with idiopathic infertility ranked in the middle as far as the number of scored points was concerned - which may suggest that only some of them were interested in the impact of lifestyle on fertility.

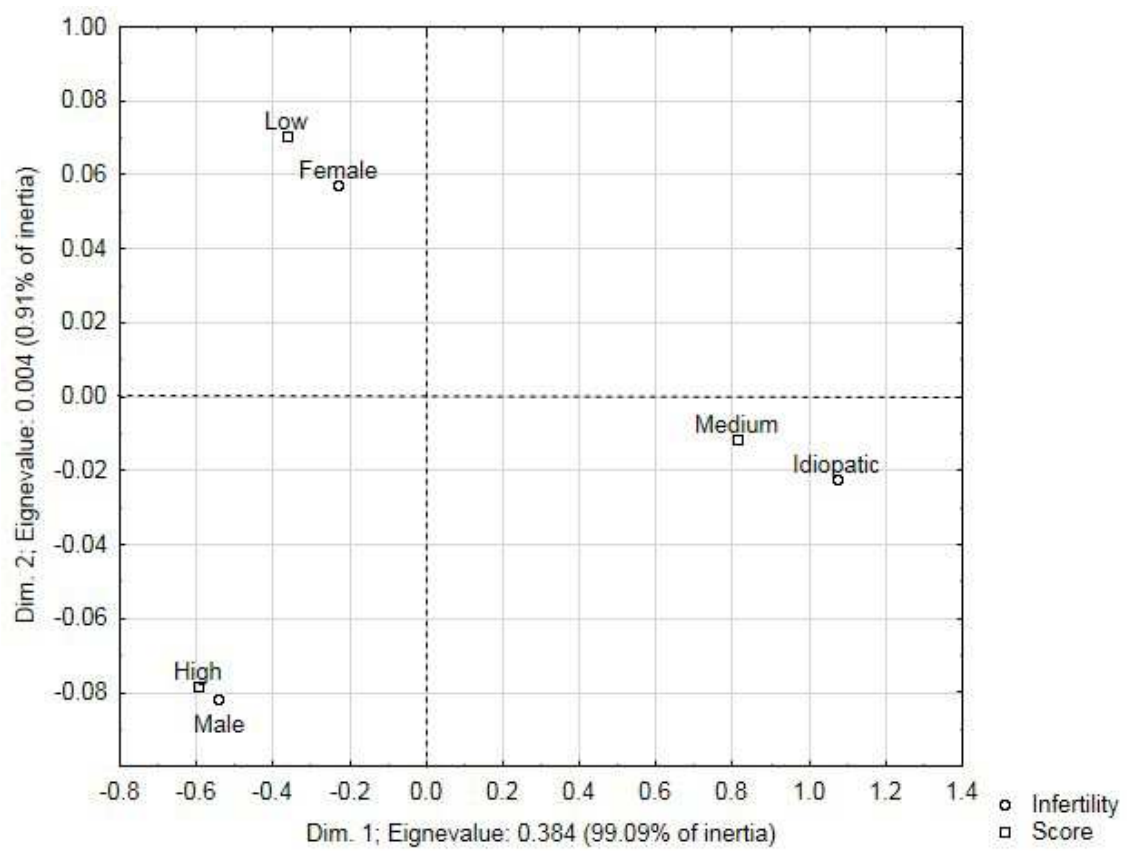

Figure 2. Correspondence map: cause of infertility vs. the number of knowledge assessment points 
The above statements can be confirmed by the fact that women with the cause of infertility on their side consumed sweets, crisps and sticks more frequently, foods which are known not to constitute part of a healthy diet, among both healthy and infertile people (Figure 3). Women whose partner was infertile consumed sweets the least frequently, which may have resulted from knowledge they had acquired; they could also have wanted to support their partners in nutritional adjustments, if such had been introduced. An excess of simple sugars, contained in sweets, may disrupt the hormonal balance in the woman's body, leading to problems with the course of the menstrual cycle (Chavarro et al., 2009). Women from couples with idiopathic infertility consumed sweets, crisps and sticks the most frequently - which may have resulted in abnormal body weight and be the cause of fertility problems.

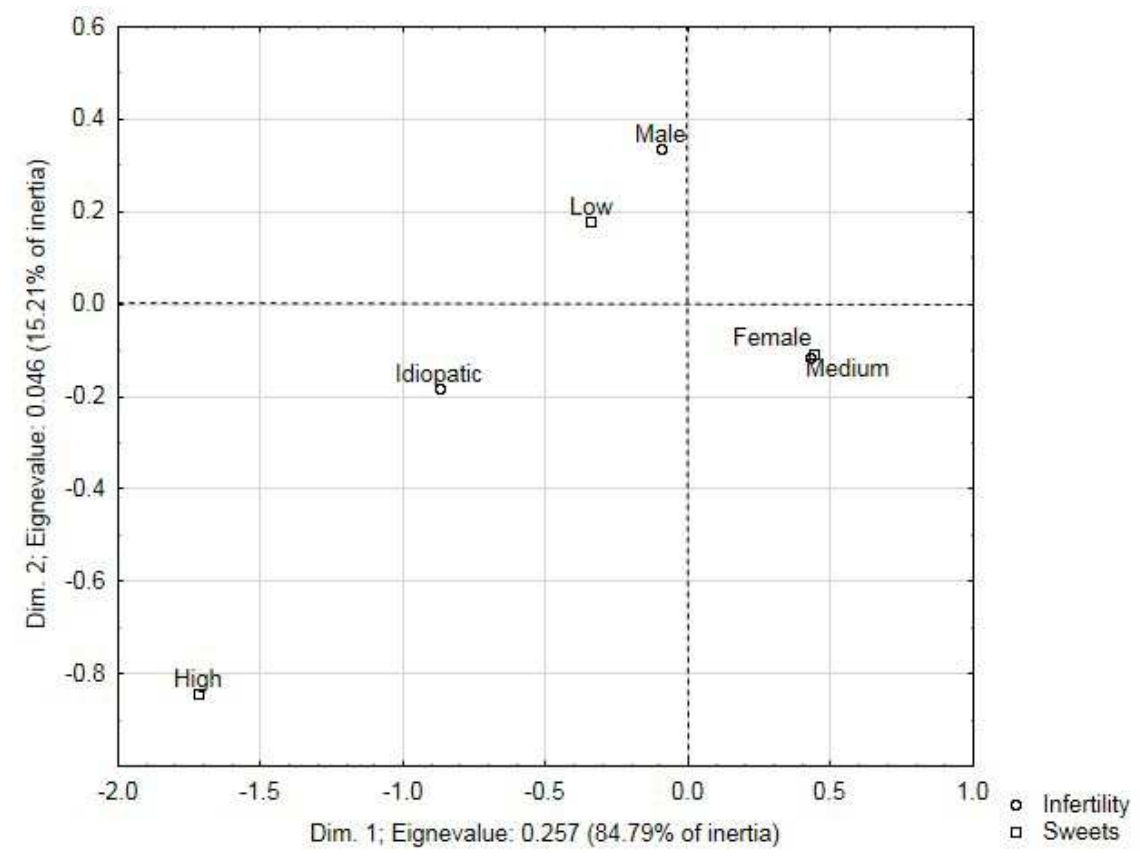

Figure 3. Correspondence map: cause of infertility vs. consumption of sweets

A similar conclusion can be drawn when analyzing the consumption of nuts and seeds, which are a source of antioxidants and unsaturated fatty acids, beneficial for fertility (Jeznach-Steinhagen \& Czerwonogródzka-Senczyna, 2013). Women whose partners were infertile consumed these products more frequently, possibly because their partners also consumed them, if the women knew that they were beneficial to fertility (Figure 4). On the other 
hand, women with the cause of infertility on their side chose nuts less frequently; women with idiopathic infertility - the least frequently; perhaps the lack of these particular ingredients and the nutritional errors were partly responsible for the infertility.

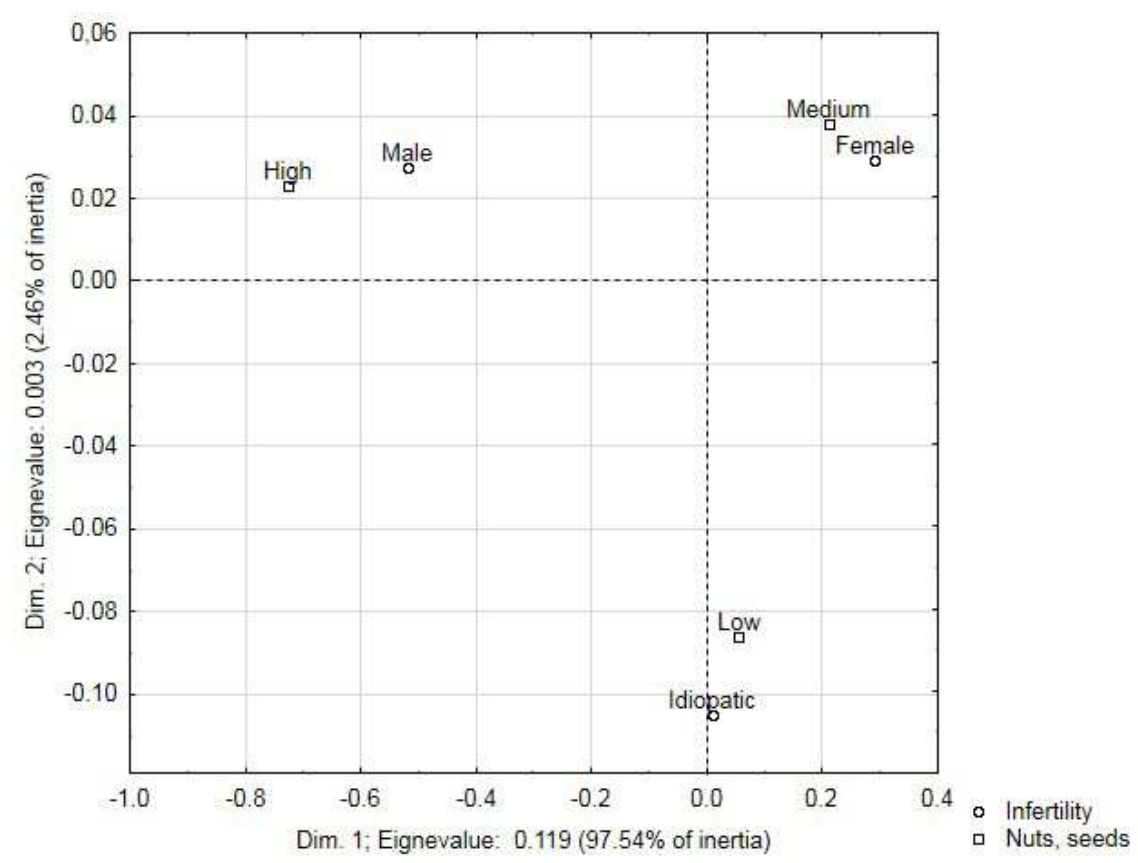

Figure 4. Correspondence map: cause of infertility vs. consumption of nuts and seeds

\section{Conclusions}

The correspondence analysis method used in this study made it possible to show that women among whom the main cause of infertility was identified as the male factor scored the highest numbers of points in the fertility diet knowledge test, whereas women among whom the main cause of infertility was identified as the female factor scored the lowest numbers of points. The differences in the area of knowledge concerning fertility diet were also confirmed by analyses performed between the same groups and the consumption of products such as sweets, nuts and seeds. The examples presented above show that correspondence analysis is very well suited to the assessment of the influence of lifestyle on fertility; in addition, it makes it possible to recognize certain correlations that may not be observed in standard statistical tests. 


\section{R E F E R E N C E S}

Chavarro, J. E., Rich-Edwards, J. W., Rosner, B. A., \& Willett, W. C. (2009). A prospective study of dietary carbohydrates quantity and quality in relation to risk of ovulatory infertility. Eur. J. Clin. Nutr., 63, 78-86.

Greencare, M. J., \& Hastie, T. (1987). The geometric Interpretation of Correspondence Analysis. Journal of the American Statistical Association, 82(398), 437-447.

Drągowski, P., Siemionow, K., Zaręba, I., Prokop, I., Rysiak, E., Cekała, E., \& Rutkowski, M. (2015). Społeczno-ekonomiczne skutki niepłodności. Polski Przeglad Nauk o Zdrowiu, 4(45), 255-258.

Gambineri, A., Laudisio, D., Marocco, C., Radellini, S., Colao, A., \& Savastano, S. (2019). Female infertility: which role for obesity? International Journal of Obesity Suplements, 9, 65-72.

Jeznach-Steinhagen, A., \& Czerwonogródzka-Senczyna, A. (2013). Dietary regimen as a part of infertility therapy of men with reduced sperm quality. Endokrynologia, Otyłość i Zaburzenia Przemiany Materii, 9 (1), 14-19.

Jończyk, J. A., \& Olszewska, A. M. (2016). The use of correspondence analysis in assessing the antecedents of innovativeness in public hospitals. Studies in Logic, Grammar and Rhetoric. Logical, Statistical and Computer Methods in Medicine, 47(60), 85-101.

Kaźmierczak, M. (2008). Empatia rodziców jako korelat indywidualnych różnic w zakresie empatii troski u dzieci. Psychologia rozwojowa, 13(3), 41-55.

Koperwas, M., \& Głowacka, M. (2017). Problem niepłodności wśród kobiet i mężczyzn - epidemiologia, czynniki ryzyka i świadomość społeczna. Aspekty zdrowia $i$ choroby Tom 2, Nr 3, 31-49.

Łukaszuk, K., Kozioł, K., Jakiel, G., Jakimiuk, A., Jędrzejczak, P., Kuczyński W., Kurzawa R., et al. (2018). Diagnostyka i leczenie niepłodności - rekomendacje Polskiego Towarzystwa Medycyny Rozrodu i Embriologii (PTMRiE) oraz Polskiego Towarzystwa Ginekologów i Położników (PTGP). Ginekologia i Perinatologia Praktyczna, 3(3), 112-140.

Milewska, A. J., Jankowska, D., Górska, U., Milewski, R., \& Wołczyński, S. (2012). Graphical representation of the relationships between qualitative variables concerning the process of hospitalization in the gynecological ward using correspondence analysis. Studies in Logic, Grammar and Rhetoric. Logical, Statistical and Computer Methods in Medicine, 29(42), 7-25.

Skreczko, K. (2017). Przyczyny niepłodności w małżeństwie - dramat bezdzietności. KWARTALNIK NAUKOWY ISSN, 1(29), 2082-7067.

Stanimir, A. (2008). Wykorzystanie analizy korespondencji w badaniach marketingowych. In Zastosowanie metod statystycznych $w$ badaniach marketingowych III (pp. 337-346). Kraków: StatSoft Polska.

Suliga, E., \& Głuszek, S. (2019). The relationship between diet, energy balance and fertility in men. Int $J$ Vitam Nutr Res, 1-13.

Szostak-Węgierek, D. (2011). Sposób żywienia a płodność. Medycyna Wieku Rozwojowego, XV, 4, 431-436. 